\title{
Analisis Sektor Unggulan dan Hubungannya dengan Ketenagakerjaan dan Kemiskinan di Provinsi Jambi
}

\section{Oleh;}

\section{Irmanelly \\ Ahmad Soleh}

Dosen STIE Muhammadiyah Jambi

\begin{abstract}
ABSTRAK
Kemiskinan merupakan permasalahan terbesar dalam pembangunan ekonomi, rendahnya kemiskinan merupakan cerminan keberhasilan dalam pembangunan yang ada. Penelitian ini berjudul analisis sektor unggulan dan hubungannya dengan ketenagakerjaan dan kemiskinan di Provinsi Jambi, ini bertujuan. untuk mengidentifikasi dan menganalisis sektor unggulan di Provinsi Jambi. Selanjutnya penelitian ini juga dimaksudkan untuk mengetahui hubungan antara sektor unggulan dengan ketenagakerjaan dan kemiskinan.

Alat analisis yang digunakan adalah Location Quotient (SLQ \& DLQ); Shift Share (Esteban-Marquillas) dan Indeks Spesialisasi. Sedangkan untuk mengetahui hubungan sektor unggulan dengan ketenagakerjaan dan kemiskinan digunakan alat uji Korelasi Pearson. Data yang dipakai dalam penelitian adalah data sekunder dalam rentang tahun 2002 s.d 2010 dari berbagai sumber.

Hasil dari penelitian ini berdasarkan analisis SLQ, DLQ dan Shif Share adalah Sector yang yang merupakan sektor unggulan di Provinsi Jambi adalah sektor pertanian dan sektor pertambangan \& penggalian. Kedua sektor tersebut selalu konsisten memenuhi kriteria di setiap alat analisis yang digunakan.

Selanjutnya hubungan antara sektor unggulan dengan ketenagakerjaan memiliki korelasi signifikan dan searah, sedangkan hubungan antara sektor unggulan dengan kemiskinan memiliki korelasi signifikan dan berlawanan arah. Dengan demikian diharapkan pengembangan sektor unggulan di Provinsi Jambi mempunyai hubungan positif dengan ketenagakerjaan yaitu meningkatkan jumlah tenaga kerja dan mempunyai hubungan negatif dengan kemiskinan yaitu mengurangi persentase penduduk miskin.
\end{abstract}

\section{Kata kunci: kemiskinan, Pembangunan ekonomi, ketenagakerjaan dan sektor unggulan.}




\section{METODE PENELITIAN}

\section{Metode penelitian}

Metode penelitian yang digunakan dalam penelitian ini adalah metode analisis data sekunder. Data sekunder diperoleh dari instansi terkait dan kemudian data tersebut dijelaskan secara deskriptif kuantitatif dan kualitatif.

Jenis dan Sumber Data

Jenis data yang akan digunakan dalam penelitian ini adalah berupa data kuantitatif dan kualitatif. Sumber data yang digunakan dalam penelitian ini adalah data sekunder yang dikumpulkan dari instansi terkait

\section{Metode Analisis Data}

Penghitungan model analisis menggunakan pendekatan PDRB sektoral dan pendekatan tenaga kerja per sektor. Adapun model analisis yang digunakan untuk pengujian hipotesis dalam penelitian ini adalah :

\section{Model Analisis untuk Uji Hipotesis Pertama}

Model analisis yang digunakan dalam penelitian ini adalah :

a) Analisis Location Quotient (LQ)

1) Static Location Quotient (SLQ) merupakan perbandingan kontribusi nilai tambah suatu sektor di daerah bagian dan kontribusi nilai tambah sektor sejenis di daerah himpunan, dengan formula sebagai berikut:

$$
\cdot \quad r=\frac{\tau}{\bar{r}} \quad(\text { Persamaan 3.1) }
$$

Dimana :

: PDRB sektor i Provinsi jambi pada tahun penelitian

: PDB sektor i Indonesia/Nasional pada tahun penelitian

: Total PDRB Propinsi Jambi pada tahun penelitian

: Total PDB Indonesia/Nasional pada tahun penelitian

Kriterianya adalah :

- Bila SLQ > 1 menunjukkan sektor tersebut tergolong sektor basis, kelebihan produksi mampu melakukan ekspor

- Bila SLQ $<1$ menunjukkan sektor tersebut tergolong sektor non basis, kekurangan produksi tidak mampu ekspor

- Bila SLQ $=1$ menunjukkan keswasembadaan sektor (self sufficiency) 
2) Dinamic Location Quotient (DLQ), mempunyai prinsip yang sama dengan SLQ namun mengintroduksikan laju pertumbuhan dengan asumsi bahwa setiap nilai tambah sektoral maupun total nilai tambah mempunyai rata-rata laju pertumbuhan sendiri-sendiri selama periode waktu tertentu., diformulasikan sebagai berikut :

$$
=\frac{\frac{{ }^{*}}{{ }^{*}}}{\frac{{ }^{*}}{*^{*} \quad \ldots !}}
$$

(Persamaan 3.2)

Dimana :

: PDRB sektor i Provinsi Jambi pada tahun penelitian

nilai tambah sektor i di daerah referensi pada awal tahun penelitian

: total nilai tambah daerah bagian pada awal tahun penelitian

: total nilai tambah daerah referensi pada awal tahun penelitian

pertumbuhan rata-rata sektor i di daerah bagian

: pertumbuhan rata-rata sektor i di daerah referensi

: pertumbuhan rata-rata total di daerah bagian

: : pertumbuhan rata-rata total di daerah referensi

Kriterianya dalam analisis DLQ adalah :

- $\quad$ Bila DLQ $>1$ menunjukkan sektor basis dan dimasa mendatang masih bisa diharapkan tetap basis/unggul

- $\quad$ Bila DLQ $<1$ menunjukkan bukan sektor unggulan (non basis) dan dimasa mendatang belum bisa diharapkan menjadi basis/unggul

- $\quad$ Bila DLQ = 1 menunjukkan keswasembadaan (self-sufficiency) sektor tersebut dan juga dimasa mendatang diharapkan tetap bisa mencukupi

Kriteria yang digunakan dalam perbandingan analisis SLQ dengan DLQ untuk menentukan perubahan atau reposisi sektoral adalah sebagai berikut:

Tabel 3.1 Kriteria dan Kategori Reposisi Basis Sektoral Perekonomian akibat perubahan nilai SLQ dan DLQ

\begin{tabular}{|c|c|c|l|}
\hline & Kriteria & Kategori & \multicolumn{1}{c|}{ Diskripsi } \\
\hline & {$[1]$} & {$[2]$} & \multicolumn{1}{c|}{$[3]$} \\
\hline a. & $\begin{array}{c}\text { SLQ }>1 \\
\text { DLQ }>1\end{array}$ & A & $\begin{array}{l}\text { maka suatu sektor belum mengalami reposisi, artinya sektor } \\
\text { yang menjadi unggulan (basis) pada saat ini juga masih tetap } \\
\text { menjadi unggulan (basis) di masa mendatang. }\end{array}$ \\
\hline b. & $\begin{array}{l}\text { SLQ }>1 \\
\text { DLQ }<1\end{array}$ & B & $\begin{array}{l}\text { maka suatu sektor telah mengalami reposisi, artinya sektor yang } \\
\text { menjadi ungggulan (basis) pada saat ini tidak bisa diharapkan } \\
\text { menjadi unggulan (basis) di masa mendatang. }\end{array}$ \\
\hline c. & $\begin{array}{c}\text { SLQ }<1 \\
\text { DLQ }>1\end{array}$ & C & $\begin{array}{l}\text { maka suatu sektor telah mengalami reposisi, dari sektor bukan } \\
\text { unggulan (nonbasis) menjadi sektor unggulan (basis) dan masih } \\
\text { bisa diharapkan untuk menjadi unggulan dimasa mendatang. }\end{array}$ \\
\hline d. & $\begin{array}{c}\text { SLQ }<1 \\
\text { DLQ }<1\end{array}$ & D & $\begin{array}{l}\text { maka suatu sektor belum mengalami reposisi dan tetap menjadi } \\
\text { sektor bukan unggulan (nonbasis) dan tidak bisa diharapkan } \\
\text { menjadi unggulan di masa mendatang. }\end{array}$ \\
\hline
\end{tabular}


Sementara itu, jika kita lihat besaran perbandingan nilai rata-rata SLQ dengan DLQ, maka kriterianya adalah :

- Bila SLQ < DLQ menunjukkan pada saat ini merupakan sektor basis dan dimasa mendatang berpotensi kelebihan produksi / tenaga kerja

- $\quad$ Bila SLQ > DLQ menunjukkan pada saat ini merupakan sektor basis dan dimasa mendatang berpotensi kekurangan produksi / tenaga kerja

- Bila SLQ = DLQ menunjukkan potensi keswasembadaan sektor (selfsufficiency) produksi / tenaga kerja, pada saat ini maupun dimasa mendatang

\section{b) Analisis Shift Share}

Penelitian ini menggunakan pendekatan analisis Shift Share Dynamic atau Esteban-Marquillas Shift Share Analysis. Analisis ini berbeda dengan analisis Shift Share klasik dimana dalam analisis klasik diasumsikan ada tiga komponen yaitu komponen pertumbuhan nasional, komponen pertumbuhan proporsional dan komponen pertumbuhan pangsa wilayah (Budiharsono, 2001; Ricardson, 1991; Arsyad, 1999). Sedangkan Analisis shift share dinamik, menurut Herzog dan Olsen (1977) komponen pertumbuhan pangsa wilayah diurai menjadi komponen spesialisasi dan komponen kompetitif, kedua komponen ini dinamakan dengan komponen pengaruh alokasi dinotasikan dengan (Aij)

Pada penelitian ini, data yang digunakan adalah data perkembangan PDRB dan TK Provinsi Jambi dan nasional menurut lapangan usaha berdasar pada periode waktu 2002-2010 kemudian dilihat angka pertumbuhan masing-masing sektornya serta pengaruh yang timbul yaitu pengaruh pertumbuhan nasional (Nij), pengaruh bauran industri (Mij), pengaruh persaingan (C'ij) dan pengaruh alokasi (Aij) yang terdiri atas pengaruh spesialisasi(Eij-E'ij) dan pengaruh keunggulan kompetitif (rij-rin).

Rumus analisis shift-share modifikasi Esteban-Marquillas berasal dari rumus analisis shift-share klasik. Rumus shift-share klasik adalah sebagai berikut (Soepono, 1993):
$\mathrm{Dij}=\mathrm{Nij}+\mathrm{Mij}+\mathrm{Cij}$
(Persamaan 3.3)
Dimana:
Dij $=$ Perubahan pertumbuhan PDRB dan TK sektor $\mathrm{i}$ di wilayah $\mathrm{j}$
$\mathrm{Nij}=$ Eij (rn) adalah pertumbuhan regional sektor $\mathrm{i}$ di wilayah $\mathrm{j}$
Mij = Eij (rin- rn) adalah pengaruh bauran industri sektor $\mathrm{i}$ di wilayah $\mathrm{j}$
$\mathrm{Cij}=$ Eij (rij - rn) adalah persaingan sektor $\mathrm{i}$ di wilayah $\mathrm{j}$
Rij $=\left(E^{\prime} i j-\right.$ Eij $) /$ Eij adalah pertumbuhan sektor $\mathrm{i}$ di wilayah $\mathrm{j}$
Rin $=\left(E^{\prime}\right.$ in - Ein $) /$ Ein adalah pertumbuhan sektor i di wilayah $n$ 
$\mathrm{rn}=\left(\mathrm{E}^{\prime} \mathrm{n}-\mathrm{En}\right) /$ En pertumbuhan PDB total di wilayah $\mathrm{n}$

Eij $=$ PDRB sektor i Provinsi Jambi awal tahun

Ein $=$ PDB sektor i nasional awal tahun

$\mathrm{Ej}=$ Total PDRB Provinsi Jambi awal tahun

En $=$ PDB awal tahun

Seluruhnya diukur pada satu tahun dasar dan tanda (') menunjukkan tahun akhir analisis. Atau persamaan (3.3) dapat ditulis sebagai berikut:

$$
\mathrm{Dij}=\mathrm{Eij}(\mathrm{rn})+\mathrm{Eij}(\mathrm{rin}-\mathrm{rn})+\mathrm{Eij}(\mathrm{rij}-\mathrm{rn}) \quad(\text { Persamaan 3.4) }
$$

Esteban-Marquillas (1972) berusaha mengatasi satu kelemahan dari analisis shift-share klasik, yaitu masalah pembobotan yang dijumpai di pengaruh persaingan sebagai komponen ketiga. Masalah pembobotan itu adalah:

$$
\mathrm{C} \text { ij }=\text { Eij (rij-rn) }
$$

(Persamaan 3.5)

Persoalannya walaupun dua wilayah mempunyai Cij yang sama di suatu sektor, daerah dengan spesialisasi yang lebih tinggi mempunyai $\mathrm{C}$ ij yang lebih besar pula. Persamaan shift-share menurut Esteban-Marquillas mengandung unsur baru yang disebut "homothetic employment" atau pendapatan yang diharapkan di sektor i wilayah j, yang diberi notasi E’ij yang didefinisikan sebagai suatu variabel wilayah (Eij ) bila struktur wilayah sama dengan struktur nasional, atau Eij yang diharapkan.

E'ij dapat dirumuskan sebagai berikut:

$$
E^{\prime} \mathrm{ij}=\mathrm{Ej}(\mathrm{Ein} / \mathrm{En})
$$

(Persamaan 3.6)

Bila persamaan (3.6) disubtitusikan ke persamaan (3.5) maka kedudukan komponen ketiga yaitu persaingan menjadi:

$$
C^{\prime} \mathrm{ij}=\mathrm{E}^{\prime} \mathrm{ij}(\mathrm{rij}-\mathrm{rn})
$$

(Persamaan 3.7)

Dimana, C'ij adalah persaingan atau kedudukan persaingan menurut Esteban-Marquillas (pada klasik Cij) di sektor i pada perekonomian suatu wilayah $\mathrm{j}$.

Sehingga rumus shift-share menurut Esteban-Marquillas adalah sebagai berikut:

$\mathrm{Dij}=\mathrm{Nij}+\mathrm{Mij}+\left(\mathrm{C}^{\prime} \mathrm{ij}+\mathrm{Aij}\right)$

(Persamaan 3.8)

Dimana,

$\mathrm{C}^{\prime} \mathrm{ij}=\mathrm{Cij}$ (klasik) adalah pengaruh kedudukan atau pengaruh persaingan

Aij = pengaruh alokasi, dengan rumus: 


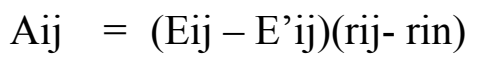

(Persamaan 3.9)

Dimana:

(Eij - E'ij) adalah spesialisasi terjadi apabila variabel wilayah nyata (Eij) lebih besar dari variabel yang diharapkan.

(rij-rin) adalah keunggulan kompetitif terjadi apabila laju pertumbuhan sektorregional lebih besar dari laju pertumbuhan nasional.

Modifikasi Esteban-Marquillas terhadap Shift-Share adalah sebagai berikut:

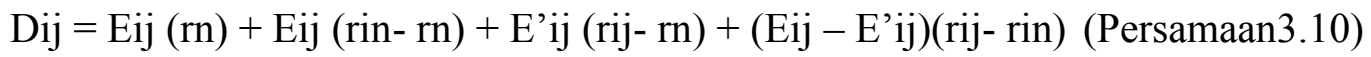

\section{c) Analisis Indeks Spesialisasi}

Analisis Indeks Spesialisasi (IS) merupakan salah satu cara untuk mengukur perilaku kegiatan ekonomi secara keseluruhan. Pendekatan pengukuran IS digunakan untuk mengukur tingkat spesialisasi diantara sektor-sektor dalam perekonomian. Pengukuran dengan menggunakan Indeks Krugman sebagaimana diterapkan oleh KIM (1995).

Besarnya nilai Indeks Spesialisasi adalah :

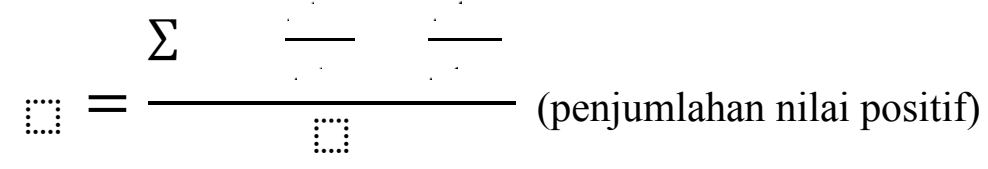

Dimana :

: : Indeks Spesialisasi sektor i (jumlah yang “+”)

: Nilai PDRB / TK sektor i diwilayah studi

: : Total PDRB / TK di wiliyah studi

: $\mathrm{PDB} / \mathrm{TK}$ sektor i di wilayah referensi

: Total PDB / TK di wilavah referensi

Kriteria pengukuran menurut KIM adalah Nilai indeks Spesialisasi yang dihasilkan yaitu dalam rentang nol dan satu ( $0 \leq \mathrm{IS} \leq 1)$,

- jika nilai IS $=0$ : berarti tidak memiliki spesialisasi pada daerah penelitian secara relatif terhadap daerah referensi. (konsentrasi suatu sektor dengan melihat tanda positif “+” nilai IS)

- jika nilai IS $=1$ : berarti memiliki spesialisasi pada daerah penelitian secara relatif terhadap daerah referensi. (konsentrasi suatu sektor dengan melihat tanda positif “+” nilai IS) 


\section{Penentuan Sektor Unggulan}

Penentuan sektor unggulan adalah dengan melihat hasil-hasil kekonsistenan hasil-hasil analisis Location Quotient (SLQ \& DLQ); Indeks Spesialiasi ( konsentrasi pada nilai positif) dan Shift Share (komponen alokasi : spesialisasi \& keunggulan kompetitif), sebagaimana terlihat dalam tabel dibawah ini.

Tabel 3.2. Kategori dan Penentuan Sektor Unggulan Provinsi Jambi Tahun $2002-2010$

\begin{tabular}{|c|c|c|c|c|c|c|}
\hline No. & $\begin{array}{l}\text { Location } \\
\text { Quotient }\end{array}$ & $\begin{array}{l}\text { Indeks } \\
\text { Spesiali } \\
\text { sasi }\end{array}$ & Shift Share & Kode & Kategori & $\begin{array}{l}\text { Penentuan } \\
\text { Sektor }\end{array}$ \\
\hline [1] & [2] & [3] & [4] & [5] & [6] & [7] \\
\hline 1. & $\begin{array}{l}\text { SLQ }>1 \\
\text { DLQ }>1\end{array}$ & $\begin{array}{c}\text { KonsistenT } \\
\text { erkon } \\
\text { sentrasi }(+) \\
(+)\end{array}$ & $\begin{array}{l}\text { punya keunggulan kompetitif, } \\
\text { spesialisasi }\end{array}$ & KU & $\begin{array}{c}\text { Konsisten } \\
\text { Unggulan }\end{array}$ & $\begin{array}{l}\text { Sektor } \\
\text { Unggulan }\end{array}$ \\
\hline & & & $\begin{array}{c}\text { punya keunggulan kompetitif, } \\
\text { spesialisasi }\end{array}$ & & & \\
\hline 2. & $\begin{array}{c}\text { SLQ }>1 \\
\text { DLQ }<1 \\
\text { atau } \\
\text { SLQ }<1 \\
\text { DLQ }>1\end{array}$ & $\begin{array}{c}\text { Tidak } \\
\text { Konsisten } \\
\text { Terkonsentr } \\
\text { asi } \\
(+)(-) \\
(-)(+)\end{array}$ & $\begin{array}{c}\text { tidak punya keunggulan } \\
\text { kompetitif, spesialisasi } \\
\text { atau } \\
\text { punya keunggulan kompetitif, } \\
\text { tidak spesialisasi } \\
\text { atau } \\
\text { tidak punya keunggulan } \\
\text { kompetitif, tidak spesialisasi }\end{array}$ & tK & $\begin{array}{l}\text { tidak } \\
\text { Konsisten }\end{array}$ & $\begin{array}{l}\text { Bukan } \\
\text { Sektor } \\
\text { Unggulan }\end{array}$ \\
\hline \multirow{3}{*}{3.} & \multirow{3}{*}{$\begin{array}{l}\mathrm{SLQ}<1 \\
\mathrm{DLQ}<1\end{array}$} & \multirow{3}{*}{$\begin{array}{l}\text { Konsisten } \\
\text { tidak } \\
\text { Terkonsentr } \\
\text { asi } \\
(-)(-)\end{array}$} & $\begin{array}{l}\text { punya keunggulan kompetitif, } \\
\text { tidak spesialisasi }\end{array}$ & $\mathrm{tK}$ & $\begin{array}{l}\text { tidak } \\
\text { Konsisten }\end{array}$ & \multirow{3}{*}{$\begin{array}{l}\text { Bukan } \\
\text { Sektor } \\
\text { Unggulan }\end{array}$} \\
\hline & & & $\begin{array}{l}\text { tidak punya keunggulan } \\
\text { kompetitif, spesialisasi }\end{array}$ & $\mathrm{tK}$ & $\begin{array}{l}\text { tidak } \\
\text { Konsisten }\end{array}$ & \\
\hline & & & $\begin{array}{l}\text { tidak punya keunggulan } \\
\text { kompetitif, tidak spesialisasi }\end{array}$ & $\mathrm{KtU}$ & $\begin{array}{l}\text { Konsiten } \\
\text { tidak } \\
\text { Unggulan }\end{array}$ & \\
\hline
\end{tabular}

\section{Pengaruh Pengganda Sektor Basis (Base Multiplier)}

Pengganda ekonomi basis menunjukkan bahwa pertumbuhan pendapatan atau tenaga kerja dalam wilayah karena penggandaan (multifikasi) jumlah pembelanjaan kembali (dalam wilayah) pendapatan dari barang dan jasa yang diproduksi didalam wilayah dan dipasarkan keluar wilayahnya (ekspor). Menurut Tiebout dalam Tarigan (2005) terdapat perbandingan dalam bentuk pendapatan atau tenaga kerja dan faktor-faktor yang terkait dengan pengganda basis. Dalam bentuk pendapatan atau tenaga kerja maka hubungan antara perubahan pendapatan atau tenaga kerja basis dengan perubahan total pendapatan atau tenaga kerja dapat dirumuskan sebagai berikut:

$$
\Delta \mathrm{Yt}=\mathrm{K} . \Delta \mathrm{Yb}
$$

(Persamaan 3.12)

Dimana:

Yt $=$ Pendapatan/tenaga kerja total (total income/labour) 
$\mathrm{Yb}=$ Pendapatan / Tenaga Kerja basis

$\mathrm{Yn}=$ Pendapatan / Tenaga Kerja non basis

$\mathrm{K}=$ Pengganda basis

$\Delta=$ perubahan pendapatan / tenaga kerja

Adapun pengganda basis dalam satuan pendapatan adalah :

$$
\left.P \quad B \quad=\begin{array}{lllll}
T & P & (T & n &
\end{array}\right)
$$

Atau dalam bentuk rumus :

$$
\mathrm{K}=\frac{\mathrm{Y}_{\mathrm{t}}}{\mathrm{Y}_{\mathrm{b}}}
$$

Oleh karena itu pendapatan atau tenaga kerja total sama dengan pendapatan atau tenaga kerja basis ditambah pendapatan atau tenaga kerja non basis. Maka rumus pengganda basis tersebut dapat dimodifikasi menjadi sebagai berikut :

$$
\mathrm{K}=\frac{\mathrm{Y}_{\mathrm{t}}}{\mathrm{Y}_{\mathrm{b}}}=\frac{1}{\frac{\mathrm{Y}_{\mathrm{b}}}{\mathrm{Y}_{\mathrm{t}}}}=\frac{1}{\frac{\mathrm{Y}_{\mathrm{t}}-\mathrm{Y}_{\mathrm{n}}}{\mathrm{Y}_{\mathrm{t}}}}=\frac{1}{\frac{\mathrm{Y}_{\mathrm{t}}}{\mathrm{Y}_{\mathrm{t}}}-\frac{\mathrm{Y}_{\mathrm{n}}}{\mathrm{Y}_{\mathrm{t}}}}=\frac{1}{1-\frac{\mathrm{Y}_{\mathrm{n}}}{\mathrm{Y}_{\mathrm{t}}}}
$$

\section{Model Analisis untuk Uji Hipotesis Kedua}

Hipotesis kedua diuji dengan menggunakan model analisis Koefisien Korelasi Pearson.

Rumusan koefisien korelasi Pearson adalah sebagai berikut :

$$
\vdots: \ldots=\frac{\sum\left(\sum\right)\left(\sum\right)}{\sum \cdot\left(\sum .\right)^{2} \sum\left(\sum\right)^{2}}
$$

Dimana :

$\mathrm{r}=$ Nilai koefisien korelasi Pearson

$\mathrm{X}=$ Sektor Unggulan (nilai location quotient)

$\mathrm{Y}=$ Penyerapan Tenaga Kerja (jumlah tenaga kerja)

Apabila nilai r sama dengan atau mendekati 0, maka hubungan antara kedua variabel sangat lemah atau tidak terdapat hubungan sama sekali. Sementara jika nilai $r$ sama dengan atau mendekati 1, maka menunjukkan hubungan antara kedua variabel adalah sangat kuat atau terdapat hubungan yang kuat.

Kriteria korelasi Pearson (r) yang digunakan dalam penelitian ini adalah (Sarwono,2007) :

\begin{tabular}{ccl}
\hline $\begin{array}{c}\text { nilai korelasi } \\
(\mathrm{r})\end{array}$ & & \multicolumn{1}{c}{ Kategori } \\
\hline$[1]$ & & \multicolumn{1}{c}{$[2]$} \\
\hline $0-0,25$ & $:$ & $\begin{array}{l}\text { korelasi sangat lemah } \\
\text { (dianggap tidak ada korelasi) }\end{array}$ \\
\hline $0,25-0,50$ & $:$ & korelasi cukup kuat \\
\hline $0,50-0,75 \mathrm{t}$ & $\vdots$ & korelasi kuat \\
\hline $0,75-1,00$ & $:$ & korelasi sangat kuat \\
\hline
\end{tabular}


Apabila korelasi (r) bernilai negatif (“_") maka menunjukkan hubungan dua variabel saling tolak belakang / berlawanan, kebalikannya jika korelasi (r) bernilai positif ("+”) maka menunjukkan hubungan dua variabel tersebut adalah searah.

Untuk menguji signifikansi koefisien korelasi Pearson tersebut digunakan alat uji t, yang dirumuskan sebagai berikut :

$$
t=r_{p} \sqrt{\frac{N-2}{1-r_{p}^{2}}}
$$

Rumusan Hipotesis untuk pengujian dua arah dinyatakan dengan notasi sebagai berikut :

Dimana $r_{p}=$ koefisien korelasi pearson

$$
\begin{aligned}
& \mathrm{H}: \quad=0 \\
& \mathrm{H} \quad: \quad \neq 0
\end{aligned}
$$

$\mathrm{H}_{0}$ : Tidak ada hubungan korelasi signifikan antara variabel sektor unggulan dengan penyerapan tenaga kerja di Provinsi Jambi.

$\mathrm{H}_{1}$ : Ada hubungan korelasi signifikan antara variabel sektor unggulan dengan penyerapan tenaga kerja di Provinsi Jambi.

Pengambilan keputusan :

Dengan membandingkan nilai $\mathrm{t}$ hitung dengan nilai $\mathrm{t}$ tabel, maka dapat ditarik suatu kesimpulan dengan ketentuan:

- Jika nilai $\mathrm{t}$ hitung < nilai $\mathrm{t}$ tabel; maka kesimpulannya adalah terima hipotesis nol, yang berarti bahwa tidak ada hubungan korelasi signifikan antara variabel sektor unggulan dengan penyerapan tenaga kerja di Provinsi Jambi.

- Jika nilai $\mathrm{t}$ hitung $\geq$ nilai $\mathrm{t}$ tabel, maka kesimpulannya adalah tolak hipotesis nol, yang berarti bahwa ada hubungan korelasi signifikan antara variabel sektor unggulan dengan penyerapan tenaga kerja di Provinsi Jambi.

\section{Model Analisis untuk Uji Hipotesis Ketiga}

Hipotesis ketiga akan diuji menggunakan alat analisis korelasi Pearson, dengan formula sebagai berikut:

$$
\ldots=\frac{\left.\sum()^{\prime}\right)\left(\sum\right)}{\sum \cdot\left(\sum \cdot\right)^{2} \sum\left(\sum\right)^{2}}
$$


Dimana :

$\mathrm{r}=$ nilai koefisien korelasi Pearson

$\mathrm{X}=$ Sektor Unggulan (nilai location quotient)

$\mathrm{Y}=$ Kemiskinan (persentase penduduk miskin)

Apabila nilai $\mathrm{r}=0$ atau mendekati 0 , maka hubungan antara kedua variabel sangat lemah atau tidak terdapat hubungan sama sekali diantara kedua variabel tersebut. Sementara jika nilai $\mathrm{r}=1$ atau mendekati 1 , maka hubungan antara kedua variabel tersebut sangat kuat atau terdapat hubungan yang kuat.

Kriteria korelasi Pearson (r) yang digunakan dalam penelitian ini adalah (Sarwono,2007) :

\begin{tabular}{ccl}
\hline $\begin{array}{c}\text { nilai korelasi } \\
(\mathrm{r})\end{array}$ & & \multicolumn{1}{c}{ Kategori } \\
\hline$[1]$ & $:$ & $\begin{array}{l}\text { korelasi sangat lemah } \\
\text { (dianggap tidak ada korelasi) }\end{array}$ \\
\hline $0-0,25$ & $\vdots$ & korelasi cukup kuat \\
& $:$ & korelasi kuat \\
$0,25-0,50$ & $:$ & korelasi sangat kuat \\
\hline $0,50-0,75$ & & \\
\hline $0,75-1,00$ &
\end{tabular}

Apabila korelasi (r) bernilai negatif (“-“) maka menunjukkan hubungan dua variabel saling tolak belakang / berlawanan, kebalikannya jika korelasi (r) bernilai positif (“+”) maka menunjukkan hubungan dua variabel tersebut adalah searah.

Rumusan Hipotesis dua arah adalah sebagai berikut :

$$
\mathrm{H}: \quad=0
$$

Dimana $r_{p}=$ koefisien korelasi pearson

$\mathrm{H}_{0}$ : Tidak ada hubungan korelasi signifikan antara variabel sektor unggulan dengan persentase penduduk miskin di Provinsi Jambi.

$\mathrm{H}_{1}$ : Ada hubungan korelasi signifikan antara variabel sektor unggulan dengan persentase penduduk miskin di Provinsi Jambi.

Untuk menguji signifikansi koefisien korelasi pearson tersebut digunakan alat uji t, yang dirumuskan sebagai berikut :

$$
t=r_{p} \sqrt{\frac{N-2}{1-r_{p}{ }^{2}}}
$$


Pengambilan keputusan :

Dengan membandingkan nilai t hitung dengan nilai $t$ tabel, maka dapat ditarik kesimpulan dengan ketentuan:

- Jika nilai t hitung < nilai t tabel; maka kesimpulannya adalah terima hipotesis nol, yang berarti bahwa tidak ada hubungan korelasi signifikan antara variabel sektor unggulan dengan persentase penduduk miskin di Provinsi Jambi.

- $\quad$ Jika nilai $\mathrm{t}$ hitung $\geq$ nilai $\mathrm{t}$ tabel, maka kesimpulannya adalah tolak hipotesis nol, yang berarti bahwa ada hubungan korelasi signifikan antara variabel sektor unggulan dengan persentase penduduk miskin di Provinsi Jambi.

\section{HASIL PEMBAHASAN}

\section{Sector ungulan}

Berdasarkan hasil analisis SLQ pendekatan PDRB menunjukkan bahwa yang menjadi sektor unggulan (sektor basis) dalam kurun waktu 2002 sampai dengan 2010 diurutkan dari nilai rata-rata SLQ yang paling besar adalah sektor (1) pertanian dengan nilai rata-rata SLQ sebesar 2,16; sektor (2) pertambangan \& penggalian sebesar 1,35; sektor (7) pengangkutan \& komunikasi sebesar 1,19 dan sektor (4) listrik, gas \& air bersih sebesar 1,10. Sedangkan Sektor-sektor yang merupakan sektor bukan unggulan (non basis) antara lain; sektor (9) jasajasa dengan nilai rata-rata SLQ sebesar 0,98; sektor (5) kontruksi sebesar 0,67; sektor (3) industri sebesar 0,51 dan sektor (8) keuangan, real estate \& jasa perusahaan sebesar 0,46. Sementara, sektor (6) perdagangan, hotel \& restoran mempunyai nilai rata-rata SLQ sebesar 1,00 sehingga dapat diartikan sebagai sektor self-sufficient yaitu sektor yang mampu swasembada dengan mencukupi atau memenuhi kebutuhan daerah sendiri.

Sedangkan Sektor unggulan di Provinsi Jambi berdasarkan penghitungan nilai ratarata DLQ yang lebih besar dari satu ( DLQ > 1) adalah sektor (1) pertanian sebesar 3,21; sektor (2) pertambangan \& penggalian sebesar 4,54; sektor (4) listrik, gas \& air bersih sebesar 1,25 dan sektor (5) kontruksi sebesar 1,18. Keempat sektor ini merupakan sektor unggulan (sektor basis) pada saat ini dan bisa diharapkan untuk tetap unggul/basis pada masa mendatang. 


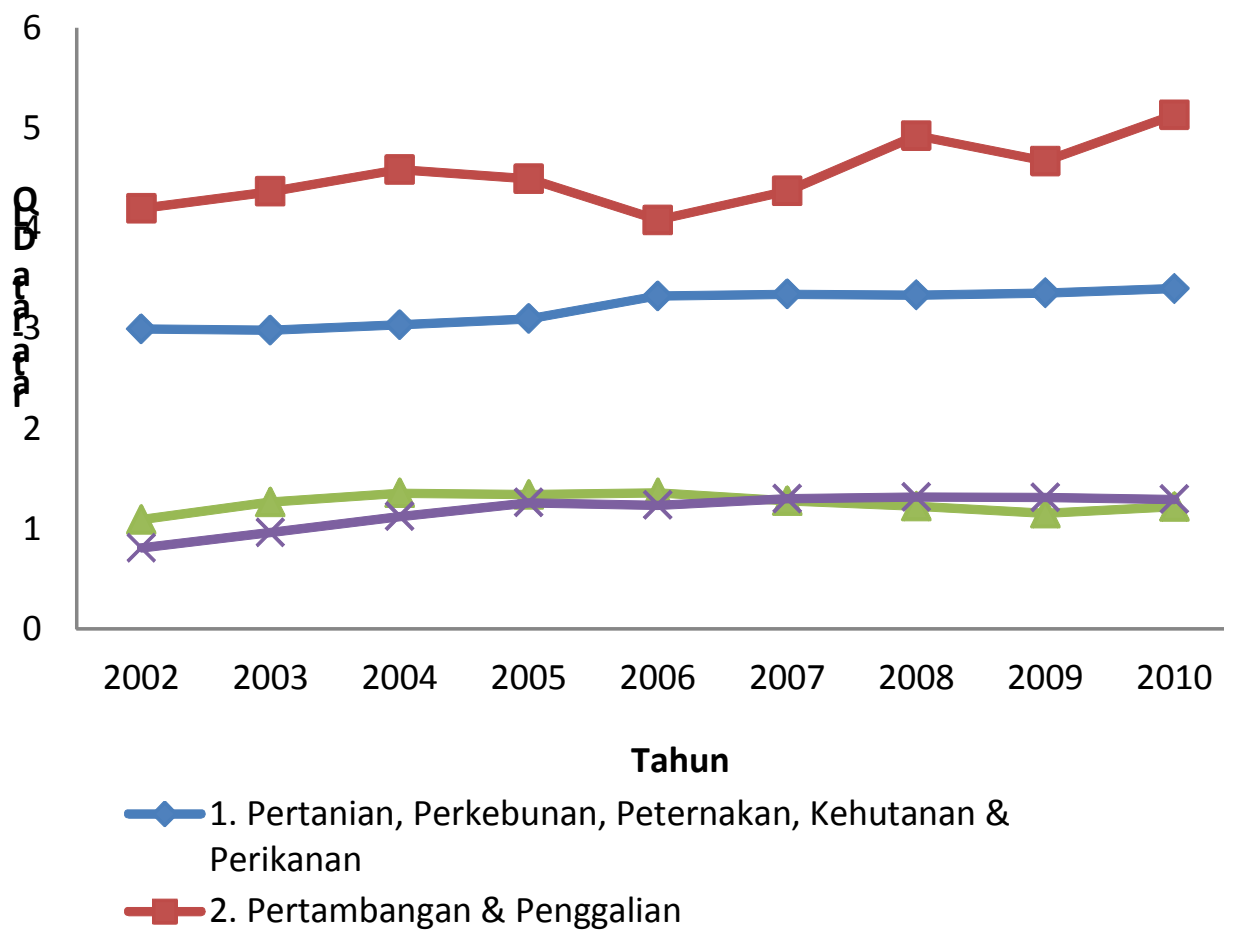

Grafik 5.c. Perkembangan Nilai Rata-rata DLQ PDRB Sektor Unggulan Provinsi Jambi Tahun $2002-2010$

\section{Perbandingan Analisis SLQ dengan DLQ PDRB}

\section{Analisis Location Quotient (SLQ \& DLQ) TK}

Berdasarkan hasil analisis SLQ Tenaga Kerja (TK) dapat diketahui sektor-sektor yang merupakan sektor unggulan (sektor basis) dan sektor bukan unggulan (sektor non basis) dalam menyerap tenaga kerja di Provinsi Jambi. Seperti terlihat pada Tabel 5.5., sektor-sektor yang merupakan sektor unggulan dengan nilai rata-rata SLQ > 1 pada tahun 2002 sampai dengan 2010 adalah sektor (1) pertanian dengan nilai rata-rata SLQ sebesar 1,42 dan sektor (2) pertambangan \& penggalian dengan nilai rata-rata SLQ sebesar 1,37.

Tabel 5.5. Hasil Perhitungan Indeks Location Quotient Statis (SLQ) TK Provinsi Jambi Tahun 2002 - 2010

\begin{tabular}{|c|c|c|c|c|c|c|c|c|c|c|}
\hline Lapangan Usaha (Sektor) & 2002 & 2003 & 2004 & 2005 & 2006 & 2007 & 2008 & 2009 & 2010 & $\begin{array}{l}\text { Rata- } \\
\text { rata } \\
\text { SLQ }\end{array}$ \\
\hline [1] & {$[2]$} & [3] & [4] & {$[5]$} & [6] & [7] & [8] & [9] & {$[10]$} & [11] \\
\hline $\begin{array}{l}\text { 1. Pertanian, Perkebunan, } \\
\text { Peternakan, Kehutanan \& } \\
\text { Perikanan }\end{array}$ & 1,38 & 1,46 & 1,51 & 1,40 & 1,38 & 1,40 & 1,43 & 1,39 & 1,45 & 1,42 \\
\hline $\begin{array}{l}\text { 2. Pertambangan \& } \\
\text { Penggalian }\end{array}$ & 1,25 & 1,25 & 1,11 & 2,39 & $\mathbf{1 , 5 5}$ & $\mathbf{0 , 8 1}$ & $\mathbf{1 , 0 0}$ & 1,51 & 1,46 & 1,37 \\
\hline 3. Industri & 0,39 & 0,49 & 0,36 & 0,30 & 0,34 & 0,34 & 0,31 & 0,27 & 0,27 & 0,34 \\
\hline $\begin{array}{l}\text { 4. Listrik, Gas \& Air } \\
\text { Bersih }\end{array}$ & 1,49 & 1,36 & 1,11 & 1,36 & 0,62 & 0,32 & 1,38 & 0,65 & 0,61 & 0,99 \\
\hline
\end{tabular}




\begin{tabular}{lcccccccccc}
\hline 5. Kontruksi & 0,70 & 0,49 & 0,59 & 0,65 & 0,81 & 0,65 & 0,70 & 0,76 & 0,77 & 0,68 \\
$\begin{array}{l}\text { 6. Perdagangan, Hotel \& } \\
\quad \text { Restoran }\end{array}$ & 0,67 & 0,71 & 0,54 & 0,72 & 0,72 & 0,77 & 0,75 & 0,76 & 0,76 & 0,71 \\
$\begin{array}{l}\text { 7. Pengangkutan \& } \\
\quad \text { Komunikasi }\end{array}$ & 0,78 & 0,67 & 0,66 & 0,86 & 0,86 & 0,91 & 0,83 & 0,86 & 0,74 & 0,80 \\
$\begin{array}{l}\text { 8. Keuangan, Real Estate \& } \\
\quad \text { Jasa Perusahaan }\end{array}$ & 0,40 & 0,38 & 1,64 & 0,50 & 0,25 & 0,36 & 0,46 & 0,67 & 0,57 & 0,58 \\
$\begin{array}{l}\text { 9. Jasa-Jasa } \\
\text { Sumber : lampiran tabel, diolah }\end{array}$ & 1,04 & 0,66 & 0,81 & 0,85 & 1,03 & 1,00 & 0,95 & 1,03 & 1,01 & 0,93 \\
\hline
\end{tabular}

\section{Analisis Shift Share Estaban Marquiles PDRB}

Hasil Analisis Shift Share Estaban Marquiles (SS E-M) pada Tabel 5.8., menunjukkan bahwa pengaruh pertumbuhan PDB Indonesia selama tahun 2002-2010 telah membawa pengaruh positif bagi PDRB Provinsi Jambi yang ditandai dengan meningkatnya PDRB Provinsi Jambi sebesar Rp. 5.781,14 M. Peningkatan ini terjadi pada semua sektor dimana peningkatan paling besar terjadi pada sektor (1) pertanian sebesar Rp. 1.791,80 M, dan terkecil pada sektor (4) listrik, gas \& air minum sebesar Rp. 36,09 M. Kondisi ini menunjukkan bahwa komponen pertumbuhan PDB Indonesia cukup memberikan pengaruh positif terhadap peningkatan PDRB Provinsi Jambi.

Tabel 5.8. Hasil Penghitungan Shift Share (Estiban Marquiles) PDRB Provinsi Jambi Tahun

\begin{tabular}{|c|c|c|c|c|c|}
\hline Lapangan Usaha (Sektor) & $\begin{array}{c}\text { Pengaruh } \\
\text { Pertumbuhan } \\
\text { Nasional } \\
\left(N_{i}\right) \\
\end{array}$ & $\begin{array}{c}\text { Pengaruh } \\
\text { Bauran } \\
\text { Industri } \\
\left(M_{i}\right) \\
\end{array}$ & $\begin{array}{l}\text { Pengaruh } \\
\text { Persaingan } \\
\quad\left(\breve{C}_{i}\right)\end{array}$ & $\begin{array}{l}\text { Pengaruh } \\
\text { Alokasi } \\
\quad\left(A_{i}\right)\end{array}$ & $\begin{array}{c}\text { Perubahan } \\
\text { Daerah } \\
\left(D_{i}\right)\end{array}$ \\
\hline$[1]$ & {$[2]$} & [3] & {$[4]$} & {$[5]$} & {$[6]$} \\
\hline $\begin{array}{l}\text { 1. Pertanian, Perkebunan, } \\
\text { Peternakan, Kehutanan \& } \\
\text { Perikanan }\end{array}$ & $1.791,80$ & $-739,45$ & 59,40 & 432,58 & $1.544,34$ \\
\hline $\begin{array}{l}\text { 2. Pertambangan \& } \\
\text { Penggalian }\end{array}$ & 812,95 & $-665,41$ & $-149,08$ & 94,58 & 93,04 \\
\hline 3. Industri & 859,68 & $-185,78$ & $-436,40$ & 41,18 & 278,68 \\
\hline $\begin{array}{l}\text { 4. Listrik, Gas \& Air } \\
\text { Bersih }\end{array}$ & 36,09 & 19,81 & 44,09 & $-1,11$ & 98,88 \\
\hline 5. Kontruksi & 149,11 & 67,27 & 886,82 & $-400,13$ & 703,07 \\
\hline $\begin{array}{l}\text { 6. Perdagangan, Hotel \& } \\
\text { Restoran }\end{array}$ & 935,83 & 195,23 & 360,61 & 0,27 & $1.491,94$ \\
\hline $\begin{array}{l}\text { 7. Pengangkutan \& } \\
\text { Komunikasi }\end{array}$ & 456,86 & $1.125,95$ & 5,23 & $-401,98$ & $1.186,06$ \\
\hline $\begin{array}{l}\text { 8. Keuangan, Real Estate \& } \\
\text { Jasa Perusahaan }\end{array}$ & 183,15 & 48,77 & $1.301,58$ & $-743,92$ & 789,57 \\
\hline 9. Jasa-Jasa & 555,68 & 33,08 & $-106,83$ & $-5,68$ & 476,25 \\
\hline Total & $5.781,14$ & $-100,52$ & $1.965,42$ & $-984,21$ & $6.661,83$ \\
\hline
\end{tabular}

Sumber : lampiran tabel, diolah

\section{Analisis Shift Share Estaban Marquiles TK}

Hasil analisis Shift Share Estaban Marquiles pada Tabel 5.8. menunjukkan bahwa pengaruh pertumbuhan penyerapan tenaga kerja (TK) Indonesia selama tahun 2002-2010, telah membawa pengaruh positif bagi penyerapan TK Provinsi Jambi yang ditandai dengan 
meningkatnya penyerapanTK Provinsi Jambi sebesar 197.745 orang. Peningkatan ini terjadi pada semua sektor dengan peningkatan paling besar pada sektor (1) pertanian sebesar 121.003 orang, dan terkecil pada sektor (4) listrik, gas dan air minum hanya sebesar 574 orang. Kondisi ini menunjukkan bahwa komponen pertumbuhan penyerapan TK Indonesia cukup memberikan pengaruh positif terhadap peningkatan penyerapan TK Provinsi Jambi.

\section{Analisis Indeks Spesialisasi (IS) PDRB}

Penggunaan alat analisis Indeks Spesialisasi (IS) sektoral adalah untuk mengukur perilaku kegiatan ekonomi secara keseluruhan dengan melihat bagaimana suatu pendapatan regional (PDRB) di Provinsi Jambi tersebar atau terkonsentrasi. Penghitungan indeks ini dengan menggunakan Indeks Krugman sebagaimana diterapkan oleh Kim (1995), dengan menghitung nilai selisih (positif) dari persentase wilayah penelitian dengan wilayah referensi didapatkan nilai diantara nol dan satu. Kriteria nilai IS adalah "bila indeks spesialisasi sektor daerah penelitian mendekati nol maka tidak memiliki spesialisasi, dan bila indeks spesialisasi mendekati satu maka memiliki spesialisasi”.

Batas tengah nilai indeks spesialisasi adalah nilai tengah antara nol dan satu yaitu nilai setengah $(0,5)$, sehingga keputusan yang dapat diambil berdasarkan nilai IS adalah semakin besar nilai IS maka semakin tinggi tingkat spesialisasi sektoral yang terkonsentrasi pada sektor-sektor yang produktif dengan nilai selisih persentase positif $(+)$.

Berdasarkan data dalam tabel 5.12., diketahui nilai rata-rata IS Provinsi Jambi selama 2001-2010 adalah sebesar 0,26 menandakan tingkat spesialisasi sektoral masih rendah, ini berarti konsentrasi sektor ekonomi tersebar cukup merata dalam perekonomian Provinsi Jambi, dimana ada empat sektor produksi yang menjadi konsentrasi pertumbuhan yakni sektor (1) pertanian; sektor (2) pertambangan \& penggalian; sektor (4) listrik, gas \& air bersih, dan sektor (7) pengangkutan \& komunikasi. Sedangkan sektor lainnya merupakan sektor under konsentrasi seperti sektor (3) industri; sektor (5) kontruksi; sektor (6) perdagangan, hotel \& restoran; sektor (8) keuangan, real estate \& jasa perusahaan dan sektor (9) jasa-jasa.

Tabel 5.12. Hasil Perhitungan Indeks Spesialisasi (IS) PDRB Provinsi Jambi Tahun $2002-2010$

\begin{tabular}{|c|c|c|c|c|c|c|c|c|c|c|}
\hline Lapangan Usaha (Sektor) & 2002 & 2003 & 2004 & 2005 & 2006 & 2007 & 2008 & 2009 & 2010 & $\begin{array}{l}\text { Rata- } \\
\text { rata } \\
\text { IS }\end{array}$ \\
\hline$[1]$ & [2] & [3] & [4] & [5] & [6] & [7] & [8] & [9] & {$[10]$} & {$[11]$} \\
\hline $\begin{array}{l}\text { 1. Pertanian, Perkebunan, } \\
\text { Peternakan, Kehutanan \& } \\
\text { Perikanan }\end{array}$ & 0,156 & 0,153 & 0,156 & 0,157 & 0,175 & 0,173 & 0,170 & 0,171 & 0,169 & 0,165 \\
\hline $\begin{array}{l}\text { 2. Pertambangan \& } \\
\text { Penggalian }\end{array}$ & 0,028 & 0,031 & 0,035 & 0,032 & 0,019 & 0,026 & 0,038 & 0,032 & 0,042 & $\mathbf{0 , 0 3 1}$ \\
\hline
\end{tabular}


3. Industri

4. Listrik, Gas \& Air

Bersih

5. Kontruksi

6. Perdagangan, Hotel \&

Restoran

7. Pengangkutan \&

Komunikasi

8. Keuangan, Real Estate \&

Jasa Perusahaan

9. Jasa-Jasa

\begin{tabular}{rrrrrrrrrr}
$-0,130$ & $-0,135$ & $-0,141$ & $-0,141$ & $-0,140$ & $-0,137$ & $-0,133$ & $-0,129$ & $-0,130$ & $-0,135$ \\
0,000 & 0,001 & 0,001 & 0,001 & 0,001 & 0,001 & 0,000 & 0,000 & 0,001 & $\mathbf{0 , 0 0 1}$ \\
$-0,030$ & $-0,026$ & $-0,021$ & $-0,017$ & $-0,018$ & $-0,016$ & $-0,016$ & $-0,016$ & $-0,017$ & $-0,020$ \\
0,000 & 0,001 & 0,001 & 0,003 & 0,004 & $-0,001$ & $-0,007$ & 0,000 & 0,001 & 0,000 \\
0,028 & 0,025 & 0,021 & 0,019 & 0,013 & 0,009 & $-0,001$ & $-0,010$ & $-0,019$ & $\mathbf{0 , 0 0 9}$ \\
$-0,056$ & $-0,055$ & $-0,054$ & $-0,054$ & $-0,054$ & $-0,051$ & $-0,046$ & $-0,041$ & $-0,038$ & $-0,050$ \\
0,004 & 0,004 & 0,002 & 0,000 & $-0,002$ & $-0,003$ & $-0,005$ & $-0,007$ & $-0,009$ & $-0,002$ \\
0,216 & 0,215 & 0,216 & 0,211 & 0,214 & 0,208 & 0,209 & 0,203 & 0,213 & $\mathbf{0 , 2 0 6}$ \\
\hline
\end{tabular}

diolah

\section{Analisis Indeks Spesialisasi (IS) TK}

Analisis Indeks Spesialisasi (IS) sektoral digunakan untuk mengukur perilaku kegiatan ekonomi secara keseluruhan dengan melihat bagaimana suatu tenaga kerja (TK) di Provinsi Jambi tersebar atau terkonsentrasi. Penghitungan indeks ini dengan menggunakan Indeks Krugman sebagaimana diterapkan oleh Kim (1995), dengan menghitung nilai selisih (positif) dari persentase wilayah penelitian dengan wilayah referensi didapatkan nilai diantara nol dan satu. Kriteria nilai IS adalah "bila indeks spesialisasi sektor daerah penelitian mendekati nol maka tidak memiliki spesialisasi, dan bila indeks spesialisasi mendekati satu maka memiliki spesialisasi”.

Batas tengah nilai indeks spesialisasi adalah nilai tengah antara nol dan satu yaitu nilai setengah $(0,5)$, sehingga keputusan yang dapat diambil berdasarkan nilai IS adalah semakin besar nilai IS maka semakin tinggi tingkat spesialisasi sektoral yang terkonsentrasi pada sektor-sektor yang menyerap tenaga kerja dengan melihat nilai selisih persentase positif $(+)$.

Tabel 5.13. Hasil Perhitungan Indeks Spesialisaasi (IS) TK Provinsi Jambi Tahun $2002-2010$

\begin{tabular}{|c|c|c|c|c|c|c|c|c|c|c|}
\hline Lapangan Usaha (Sektor) & 2002 & 2003 & 2004 & 2005 & 2006 & 2007 & 2008 & 2009 & 2010 & $\begin{array}{l}\text { Rata-rata } \\
\text { IS }\end{array}$ \\
\hline$[1]$ & [2] & [3] & [4] & [5] & [6] & [7] & [8] & [9] & [10] & [11] \\
\hline $\begin{array}{l}\text { 1. Pertanian, Perkebunan, } \\
\text { Peternakan, Kehutanan \& } \\
\text { Perikanan }\end{array}$ & 0,169 & 0,204 & 0,221 & 0,177 & 0,158 & 0,165 & 0,174 & 0,155 & 0,171 & 0,177 \\
\hline $\begin{array}{l}\text { 2. Pertambangan \& } \\
\text { Penggalian }\end{array}$ & 0,002 & 0,002 & 0,001 & 0,013 & 0,005 & $-0,002$ & 0,000 & 0,006 & 0,005 & 0,004 \\
\hline 3. Industri & $-0,080$ & $-0,063$ & $-0,076$ & $-0,089$ & $-0,082$ & $-0,082$ & $-0,084$ & $-0,089$ & $-0,094$ & $-0,082$ \\
\hline $\begin{array}{l}\text { 4. Listrik, Gas \& Air } \\
\text { Bersih }\end{array}$ & 0,001 & 0,001 & 0,000 & 0,001 & $-0,001$ & $-0,001$ & 0,001 & $-0,001$ & $-0,001$ & 0,000 \\
\hline 5. Kontruksi & $-0,014$ & $-0,024$ & $-0,020$ & $-0,017$ & $-0,009$ & $-0,018$ & $-0,016$ & $-0,013$ & $-0,012$ & $-0,016$ \\
\hline $\begin{array}{l}\text { 6. Perdagangan, Hotel \& } \\
\text { Restoran }\end{array}$ & $-0,064$ & $-0,056$ & $-0,093$ & $-0,054$ & $-0,056$ & $-0,047$ & $-0,051$ & $-0,050$ & $-0,050$ & $-0,058$ \\
\hline $\begin{array}{l}\text { 7. Pengangkutan \& } \\
\text { Komunikasi }\end{array}$ & $-0,011$ & $-0,017$ & $-0,020$ & $-0,009$ & $-0,008$ & $-0,005$ & $-0,010$ & $-0,008$ & $-0,014$ & $-0,011$ \\
\hline $\begin{array}{l}\text { 8. Keuangan, Real Estate \& } \\
\text { Jasa Perusahaan }\end{array}$ & $-0,007$ & $-0,009$ & 0,008 & $-0,006$ & $-0,011$ & $-0,009$ & $-0,008$ & $-0,005$ & $-0,007$ & $-0,006$ \\
\hline 9. Jasa-Jasa & 0,005 & $-0,038$ & $-0,021$ & $-0,017$ & 0,004 & 0,000 & $-0,006$ & 0,004 & 0,001 & $-0,008$ \\
\hline Total & 0,176 & 0,207 & 0,222 & 0,191 & 0,163 & 0,163 & 0,174 & 0,161 & 0,177 & 0,182 \\
\hline
\end{tabular}


Berdasarkan data dalam tabel diatas, diketahui nilai rata-rata IS Provinsi Jambi selama kurun waktu 9 tahun adalah sebesar 0,182 menandakan tingkat spesialisasi sektoral masih rendah, ini berarti konsentrasi sektor yang menyerap tenaga kerja tersebar cukup merata dalam perekonomian Provinsi Jambi, dimana hanya dua sektor yang menjadi konsentrasi pertumbuhan penyerapan tenaga kerja dengan nilai selisih positif $(+)$ yaitu sektor (1) pertanian dan sektor (2) pertambangan \& penggalian. Sedangkan sektor ekonomi lainnya merupakan sektor-sektor under konsentrasi dalam penyerapan tenaga kerja antara lain : sektor (3) industri; sektor (4) listrik, gas \& air bersih; sektor (5) kontruksi; sektor (6) perdagangan, hotel \& restoran; sektor (7) pengangkutan \& komunikasi; sektor (8) keuangan, real estate \& jasa perusahaan; dan sektor (9) jasa-jasa.

\section{Konsistensi Hasil Penghitungan antar Analisis (LQ, IS \& SS) dan Penentuan Sektor Unggulan}

Sektor unggulan merupakan sektor ekonomi yang memiliki gabungan kriteria seperti : sektor basis pada saat ini dan juga mendatang; memiliki keunggulan kompetitif; keunggulan komperatif atau spesialisasi / konsentrasi, jika dibandingkan dengan sektor ekonomi yang sama pada wilayah lainnya. Sektor ini menjadi andalan perekonomian suatu daerah yang diharapkan dapat bersaing dengan sektor yang sama di daerah lain, sektor ini juga mampu memenuhi ekspor pasar di luar daerah. Suatu sektor akan dapat dikategorikan sebagai sektor unggulan bilamana dalam setiap analisis location quotient (SLQ \&, DLQ), indeks spesialisasi dan shift share selalu konsisten memenuhi kriteria yang ditentukan.

Dapat diketahui, sektor (1) pertanian adalah sektor basis pertama berdasarkan penghitungan SLQ PDRB $(2,16)$ dan SLQ TK $(1,42)$ hal ini menunjukkan bahwa sektor pertanian jika dilihat dari poduksi merupakan sektor yang potensial dalam menggerakan perekonomian dan mempunyai kecenderungan ekspor, sementara jika dilihat dari tenaga kerja merupakan sektor yang mempunyai peranan lebih dari cukup dalam menyerap tenaga di Provinsi Jambi.

Tabel 5.14. Penentuan Sektor Unggulan berdasarkan Konsistensi dalam Penghitungan SLQ, DLQ, IS dan Shift Share Provinsi Jambi Tahun $2002-2010$

\begin{tabular}{ccccccccc}
\hline & \multicolumn{2}{c}{$\begin{array}{c}\text { Location } \\
\text { Quotient } \\
\text { Lapangan Usaha (Sektor) }\end{array}$} & $\begin{array}{c}\text { Location } \\
\text { Quotient } \\
\text { Dinamis }\end{array}$ & \multicolumn{2}{c}{$\begin{array}{c}\text { Indeks } \\
\text { Spesialisasi }\end{array}$} & \multicolumn{2}{c}{$\begin{array}{c}\text { Shift Share } \\
\text { (alokasi) }\end{array}$} \\
\cline { 2 - 9 } & PDRB & TK & PDRB & TK & PDRB & TK & PDRB & TK \\
\hline [1] & {$[2]$} & {$[3]$} & {$[4]$} & {$[5]$} & {$[6]$} & {$[7]$} & {$[8]$} & {$[9]$} \\
\hline $\begin{array}{c}\text { 1. Pertanian, Perkebunan, } \\
\text { Peternakan, Kehutanan \& } \\
\text { Perikanan }\end{array}$ & $\mathbf{2 , 1 6}$ & $\mathbf{1 , 4 2}$ & $\mathbf{3 , 2 1}$ & $\mathbf{6 , 1 7}$ & $\mathbf{0 , 1 6 5}$ & $\mathbf{0 , 1 7 7}$ & $\mathbf{4 3 2 , 5 8}$ & $\mathbf{1 9 . 3 5 3}$ \\
\hline
\end{tabular}




\begin{tabular}{lcccccccc}
\hline $\begin{array}{l}\text { 2. Pertambangan \& } \\
\text { Penggalian }\end{array}$ & $\mathbf{1 , 3 5}$ & $\mathbf{1 , 3 7}$ & $\mathbf{4 , 5 4}$ & $\mathbf{1 , 3 8}$ & $\mathbf{0 , 0 3 1}$ & $\mathbf{0 , 0 0 4}$ & $\mathbf{9 4 , 5 8}$ & $\mathbf{8 6 3}$ \\
\hline 3. Industri & 0,51 & 0,34 & 0,42 & $-0,38$ & $-0,135$ & $-0,082$ & $41,18^{*}$ & $28.172 *$ \\
\hline $\begin{array}{l}\text { 4. Listrik, Gas \& Air } \\
\text { Bersih }\end{array}$ & $\mathbf{1 , 1 0}$ & 0,99 & $\mathbf{1 , 2 5}$ & $-1,49$ & $\mathbf{0 , 0 0 1}$ & $\mathbf{0 , 0 0 0}$ & $-1,11$ & -778 \\
\hline $\begin{array}{l}\text { 5. Kontruksi } \\
\begin{array}{l}\text { 6. Perdagangan, Hotel \& } \\
\text { Restoran }\end{array}\end{array}$ & 0,67 & 0,68 & $\mathbf{1 , 1 8}$ & 0,80 & $-0,020$ & $-0,016$ & $-400,13$ & -3.088 \\
\hline $\begin{array}{l}\text { 7. Pengangkutan \& } \\
\text { Komunikasi }\end{array}$ & 1,00 & 0,71 & 1,00 & 0,95 & $\mathbf{0 , 0 0 0}$ & $-0,058$ & 0,27 & -16.217 \\
\hline $\begin{array}{l}\text { 8. Keuangan, Real Estate \& } \\
\text { Jasa Perusahaan }\end{array}$ & 0,46 & 0,58 & 0,87 & 0,80 & $-0,050$ & $-0,006$ & $-743,92$ & -6.557 \\
\hline $\begin{array}{l}\text { 9. Jasa-Jasa } \\
\text { Total }\end{array}$ & 0,98 & 0,93 & 0,69 & 0,74 & $-0,002$ & $-0,008$ & $-5,68$ & 140 \\
\hline
\end{tabular}

Sumber : lampiran tabel, data diolah

Sedangkan jika dilihat dari hasil penghitungan DLQ PDRB $(3,21)$ dan DLQ TK $(6,17)$ maka dapat diketahui bahwa sektor (1) pertanian pada saat ini merupakan sektor basis dan juga untuk masa mendatang masih bisa diharapkan tetap basis/unggul baik dilihat dari kemampuan produktifitas sektor ini, demikian juga di masa mendatang masih bisa diharapkan untuk tetap basis/unggul dilihat dari kemampuan menyerap tenaga kerja.

Terlihat pada tabel 5.14. kolom enam dan tujuh, hasil penghitungan indeks spesialisasi untuk sektor (1) pertanian sebesar 0.165 dengan menggunakan data PDRB dan didapatkan dengan menggunakan data TK nilai indeks ini sebesar 0,177. Kedua nilai tersebut bertanda positif sehingga dapat dikatakan sebagai sektor unggulan konsentrasi pertumbuhan dan sektor unggulan konsentrasi penyerap tenaga kerja. Selama kurun waktu penelitian sektor pertanian selalu bertanda positif, sehingga dapat dikatakan selalu konsisten pada posisi terkonsentrasi.

Berdasarkan penghitungan Shift Share Esteban-Marquillas diketahui pengaruh alokasi (allocation effect) sektor pertanian yang terdiri dari komponen keunggulan kompetitif (Eij-E'ij) nilai PDRB sebesar Rp 1.686,04 M dan nilai TK sebesar 184.445 orang, sedangkan komponen spesialisasi (rin-rij) nilai PDRB sebesar 0,257 dan nilai TK sebesar 0,105. Dengan demikian sektor pertanian merupakan sektor yang mempunyai keunggulan kompetitif dan sektor yang terspesialisasi baik dari penghitungan PDRB maupun TK sehingga dapat disimpulkan bahwa sektor ini merupakan sektor unggulan.

Sektor (2) pertambangan \& penggalian adalah sektor unggulan kedua berdasarkan penghitungan SLQ PDRB $(1,35)$ dan SLQ TK $(1,37)$, hal ini menunjukkan bahwa sektor ini jika dilihat dari poduksi juga merupakan sektor unggulan kedua setelah sektor pertanian yang potensial dalam menggerakan perekonomian dan mempunyai kecenderungan ekspor, demikian juga jika dilihat dari tenaga kerja merupakan sektor unggulan kedua setelah sektor 
pertanian yang mempunyai peranan lebih dari cukup dalam menyerap tenaga di Provinsi Jambi.

Sedangkan jika dilihat dari penghitungan DLQ PDRB $(4,54)$ dan DLQ TK $(1,38)$ maka sektor pertambangan \& penggalian pada saat ini sebagai sektor unggulan dan untuk masa mendatang juga masih bisa diharapkan tetap unggul baik dilihat dari produksi maupun tenaga kerja.

Sebagaimana sektor (1) pertanian, berdasarkan tabel 5.14 kolom enam dan tujuh, hasil penghitungan indeks spesialisasi untuk sektor (2) pertambangan \& penggalian sebesar 0.031 dengan menggunakan data PDRB dan menggunakan data TK nilai indeks ini sebesar 0,004. Kedua nilai tersebut bertanda positif sehingga dapat dikatakan sebagai sektor unggulan konsentrasi pertumbuhan dan sektor unggulan konsentrasi penyerap tenaga kerja. Selama kurun waktu penelitian sektor (2) pertambangan \& penggalian juga selalu bertanda positif, sehingga dapat dikatakan selalu konsisten pada posisi terkonsentrasi.

Berdasarkan penghitungan Shift Share Esteban-Marquillas diketahui pengaruh alokasi (allocation effect) sektor (2) pertambangan \& penggalian yang terdiri dari komponen keunggulan kompetitif (Eij-E' $i j$ ) nilai PDRB sebesar Rp 299,53 M dan nilai TK sebesar 1.849 orang, sedangkan komponen spesialisasi (rin-rij) nilai PDRB sebesar 0,316 dan nilai TK sebesar 0,467 .

Dengan demikian sektor (2) pertambangan \& penggalian merupakan sektor yang mempunyai keunggulan kompetitif dan sektor yang terspesialisasi baik dari penghitungan PDRB maupun TK sehingga dapat disimpulkan bahwa sektor ini juga merupakan sektor unggulan kedua setelah sektor (1) pertanian.

Tabel 5.15. Kategori dan Penentuan Sektor Unggulan Provinsi Jambi Tahun $2002-2010$

\begin{tabular}{|c|c|c|c|c|c|c|}
\hline No. & $\begin{array}{l}\text { Location } \\
\text { Quotient }\end{array}$ & $\begin{array}{c}\text { Indeks Spesiali } \\
\text { sasi } *\end{array}$ & Shift Share & $\begin{array}{c}\text { Kod } \\
\mathrm{e}\end{array}$ & Kategori & Sektor \\
\hline [1] & {$[2]$} & {$[3]$} & [4] & {$[5]$} & [6] & [7] \\
\hline 1. & $\begin{array}{l}\mathrm{SLQ}>1 \\
\mathrm{DLQ}>1\end{array}$ & $\begin{array}{c}\text { Konsisten } \\
\text { Terkonsentrasi } \\
\text { (+) PDRB; (+) TK }\end{array}$ & $\begin{array}{c}\text { punya keunggulan kompetitif, } \\
\text { spesialisasi }\end{array}$ & $\mathbf{K U}$ & $\begin{array}{l}\text { Konsisten } \\
\text { Unggulan }\end{array}$ & $\begin{array}{c}1 \\
\text { dan } \\
2\end{array}$ \\
\hline \multirow[b]{2}{*}{2.} & \multirow[b]{2}{*}{$\begin{array}{c}\mathrm{SLQ}>1 \\
\mathrm{DLQ}<1 \\
\text { atau } \\
\mathrm{SLQ}<1 \\
\mathrm{DLQ}>1\end{array}$} & \multirow[b]{2}{*}{$\begin{array}{c}\text { Tidak Konsisten } \\
\text { Terkonsentrasi } \\
\text { (+) PDRB; (-) TK } \\
\text { atau } \\
\text { (-) PDRB; (+) TK }\end{array}$} & $\begin{array}{c}\text { punya keunggulan kompetitif, } \\
\text { spesialisasi }\end{array}$ & & & \multirow[b]{2}{*}{$\begin{array}{c}4 \\
5 \\
6 \\
\text { dan } \\
7\end{array}$} \\
\hline & & & $\begin{array}{c}\text { tidak punya keunggulan } \\
\text { kompetitif, spesialisasi } \\
\text { atau } \\
\text { punya keunggulan kompetitif, } \\
\text { tidak spesialisasi } \\
\text { atau } \\
\text { tidak punya keunggulan } \\
\text { kompetitif, tidak spesialisasi }\end{array}$ & $\mathrm{tK}$ & $\begin{array}{l}\text { tidak } \\
\text { Konsisten }\end{array}$ & \\
\hline
\end{tabular}




\begin{tabular}{|c|c|c|c|c|c|c|}
\hline \multirow{3}{*}{3.} & \multirow{3}{*}{$\begin{array}{l}\mathrm{SLQ}<1 \\
\mathrm{DLQ}<1\end{array}$} & \multirow{3}{*}{$\begin{array}{l}\text { Konsisten } \\
\text { tidak Terkonsentrasi } \\
\text { (-) PDRB; (-) TK }\end{array}$} & $\begin{array}{c}\text { punya keunggulan kompetitif, } \\
\text { tidak spesialisasi }\end{array}$ & $\mathrm{tK}$ & $\begin{array}{l}\text { tidak } \\
\text { Konsisten }\end{array}$ & 9 \\
\hline & & & $\begin{array}{l}\text { tidak punya keunggulan } \\
\text { kompetitif, spesialisasi }\end{array}$ & $\mathrm{tK}$ & $\begin{array}{l}\text { tidak } \\
\text { Konsisten }\end{array}$ & 8 \\
\hline & & & $\begin{array}{l}\text { tidak punya keunggulan } \\
\text { kompetitif, tidak spesialisasi }\end{array}$ & $\mathrm{KtU}$ & $\begin{array}{l}\text { Konsiten } \\
\text { tidak } \\
\text { Unggulan }\end{array}$ & 3 \\
\hline
\end{tabular}

Sumber : lampiran, data diolah

Keterangan: *) nilai positif/negatif IS PDRB dan TK

$K U=$ Konsisten Unggulan

$K t U=$ Konsisten tidak Unggulan

$t K=$ tidak Konsisten

Penentuan sektor unggulan didasarkan pada penghitungan analisis Location Quotient Statis (SLQ), Location Quotient Dinamis (DLQ) dan Shift Share (SS) dengan menggunakan data PDRB dan TK selama kurun waktu 2002 - 2010 yaitu dengan melihat konsistensinya. Suatu sektor dikatakan konsisten jika disetiap penghitungan analisis tidak mengalami perubahan kategori sebagai sektor unggulan atau bukan sektor unggulan (belum mengalami reposisi). Konsisten dibedakan menjadi Konsisten Unggulan (KU) dan Konsisten tidak Unggulan (KtU). Sektor dikatakan KU jika nilai penghitungan SLQ dan DLQ lebih dari satu (basis/unggul), nilai IS konsisten terkonsentrasi, serta hasil Shift Share punya keunggulan kompetitif dan spesialisasi. Sedangkan tidak Konsisten (tK) jika sektor mengalami perubahan dari unggulan menjadi tidak unggulan atau sebaliknya (mengalami reposisi sektoral).

Sektor yang dikategorikan konsisten unggulan (KU) hanya dua sektor yaitu sektor (1) pertanian dan sektor (2) pertambangan \& penggalian. Kedua sektor tersebut nilai rata-rata SLQ dan DLQ lebih dari satu, nilai Indeks Spesialisasi terkonsentrasi dengan tanda positif (+) serta Shift Share mempunyai keunggulan kompetitif dan spesialisasi.

Sektor yang dikategorikan tidak konsisten (tK) sebanyak empat sektor antara lain yaitu sektor (4) listrik, gas \& air bersih, sektor (5) kontruksi, sektor (6) perdagangan, hotel \& restoran dan sektor (7) pengangkutan \& komunikasi. Keempat sektor tersebut nilai rata-rata SLQ dan DLQ mengalami perubahan pertamanya lebih dari satu menjadi kurang dari satu atau sebaliknya, sementara nilai Indeks Spesialisasi dan Shift Share tidak dipertimbangkan dikarenakan kriteria SLQ dan DLQ sudah tidak konsisten.

Sektor yang dikategorikan konsisten tidak unggulan $(\mathrm{KtU})$ hanya tiga sektor yaitu sektor (3) industri, sektor (8) keuangan, real estate \& jasa perusahaan dan sektor (9) jasa-jasa. Ketiga sektor tersebut nilai rata-rata SLQ dan DLQ kurang dari satu, nilai indeks spesialisasi tidak terkonsentrasi (negatif) sementara Shift Share sektor (3) industri tidak mempunyai keunggulan kompetitif dan tidak spesialisasi, sedangkan Shift Share sektor (9) jasa-jasa 
mempunyai keunggulan kompetitif dan tidak spesialisasi, serta Shift Share sektor (8) keuangan, real estate \& jasa perusahaan tidak mempunyai keunggulan kompetitif dan spesialisasi.

Berdasarkan hasil konsistensi setiap analisis diatas, maka dapat ditentukan sebagai sektor unggulan adalah sektor (1) pertanian dan sektor (2) pertambangan \& penggalian. Kedua sektor ini selama kurun waktu 9 tahun selalu konsisten sebagai sektor yang bisa diunggulkan untuk setiap penghitungan analisis. Sehubungan kadar atau derajat keunggulan berdasarkan nilai-nliai yang diperoleh untuk sektor pertanian lebih tinggi dibandingkan sektor pertambangan \& penggalian, maka dapat ditentukan sektor pertanian sebagai sektor unggulan pertama dan sektor pertambangan sebagai sektor unggulan kedua Provinsi Jambi. Sektor ungggulan yang dominan berdasarkan data PDRB adalah sektor pertanian sub sektor perkebunan, sementara TK sebatas data per sektor.

\section{Pengaruh Pengganda Basis (Base Multiflier)}

Pengganda pendapatan basis dihitung dengan membandingkan total pendapatan / total tenaga kerja pada suatu wilayah dengan pendapatan / tenaga kerja dari sektor basis (unggulan). Besarnya penggaruh pengganda ini akan mendorong pertumbuhan ekonomi atau penyerapan tenaga kerja pada wilayah tersebut.

Tabel 5.16. Koefisien Pengganda Pendapatan dan Penyerapan Tenaga Kerja Sektor Unggulan Provinsi Jambi Tahun 2002 - 2010

\begin{tabular}{|c|c|c|c|c|}
\hline \multirow{2}{*}{ Tahun } & \multicolumn{2}{|c|}{$\begin{array}{l}\text { Koefisien Pengganda } \\
\text { Pendapatan }\end{array}$} & \multicolumn{2}{|c|}{$\begin{array}{c}\text { Koefisien Pengganda } \\
\text { Penyerapan Tenaga kerja }\end{array}$} \\
\hline & $\begin{array}{c}\text { Pengganda Basis } \\
\text { Pendapatan }\end{array}$ & $\begin{array}{c}\text { Rasio } \\
\text { Unggulan }\end{array}$ & $\begin{array}{r}\text { Pengganda Basis } \\
\text { Penyerapan TK } \\
\end{array}$ & $\begin{array}{c}\text { Rasio } \\
\text { Unggulan }\end{array}$ \\
\hline$[1]$ & {$[2]$} & [3] & {$[4]$} & {$[5]$} \\
\hline 2002 & 2,22 & 1,22 & 1,61 & 0,61 \\
\hline 2003 & 2,26 & 1,26 & 1,52 & 0,52 \\
\hline 2004 & 2,29 & 1,29 & 1,50 & 0,50 \\
\hline 2005 & 2,34 & 1,34 & 1,56 & 0,56 \\
\hline 2006 & 2,34 & 1,34 & 1,69 & 0,69 \\
\hline 2007 & 2,36 & 1,36 & 1,71 & 0,71 \\
\hline 2008 & 2,34 & 1,34 & 1,70 & 0,70 \\
\hline 2009 & 2,37 & 1,37 & 1,76 & 0,76 \\
\hline 2010 & 2,36 & 1,36 & 1,75 & 0,75 \\
\hline rata-rata & 2,32 & 1,32 & 1,64 & 0,64 \\
\hline
\end{tabular}

Sumber : Lampiran, data diolah

Keterangan :

Sektor Unggulan

sektor pertanian dan sektor pertambangan \& penggalian

Sektor bukan Unggulan sektor industri; sektor listrik, gas \& air bersih; sektor kontruksi; sektor perdagangan, hotel \& restoran; sektor pengangkutan \& komunikasi; sektor keuangan, real estate \& jasa perusahaan dan sektor jasa-jasa 
Pada tabel 5.16., terlihat koefisien pengganda pendapatan sektor unggulan (basis) menunjukkan rata-rata diatas 2,31 dan dari tahun ke tahun terlihat kecenderungan semakin membesar. Hal ini mengandung pengertian bahwa sektor-sektor unggulan (basis) mampu memberikan dampak terhadap pembentukan PDRB Provinsi Jambi sebesar 2,31 kali dari total PDRB yang dihasilkan oleh sektor unggulan (basis) ini. Sementara rasio unggulan rata-rata sebesar 1,32 yang berarti bila pendapatan sektor unggulan sebesar 100 persen maka pendapatan disektor bukan unggulan sebesar 132 persen.

Sedangkan koefisien pengganda penyerapan tenaga kerja sektor unggulan (basis) menunjukkan rata-rata diatas 1,63 dan dari tahun ke tahun juga terlihat kecenderungan semakin membesar. Hal ini mengandung pengertian bahwa sektor-sektor unggulan (basis) mampu memberikan dampak terhadap penyerapan tenaga kerja sebesar 1,63 kali dari total penyerapan tenaga kerja Provinsi Jambi yang dihasilkan oleh sektor unggulan (basis) ini. Dengan melihat rasio unggulan rata-rata sebesar 0,64 yang berarti bila penyerapan tenaga kerja sektor unggulan sebesar 100 persen maka penyerapan tenaga kerja disektor bukan unggulan sebesar 64 persen.

\section{Hubungan Sektor Unggulan dengan Ketenagakerjaan}

Untuk mengetahui hubungan antara sektor unggulan dengan ketenagakerjaan maka digunakan analisis koefisien korelasi Pearson. Variabel yang digunakan untuk menentukan hubungan korelasi yaitu variabel sektor unggulan dan variabel ketenagakerjaan. Untuk variabel sektor unggulan terdiri dari sektor unggulan 1 (nilai LQ sektor pertanian) dan unggulan 2 (nilai LQ sektor pertambangan \& penggalian) menggunakan nilai hasil penghitungan location quotient, sedangkan untuk variabel ketenagakerjaan menggunakan jumlah tenaga kerja.

Berdasarkan penghitungan statistik (hasil output SPSS) tentang koefisien korelasi Pearson, didapatkan bahwa korelasi antara sektor unggulan 1 (pertanian) dengan jumlah tenaga kerja menghasilkan angka 0,697. Terlihat nilai koefisien korelasi Pearson bernilai positif yang menunjukkan hubungan searah dan kisaran ini menunjukkan korelasi kuat. Yang berarti semakin tinggi sektor pertanian (unggulan 1) maka jumlah tenaga kerja semakin meningkat, begitu juga sebaliknya.

Untuk mengetahui apakah angka korelasi yang diciptakan benar-benar signifikan, kita dapat menggunakan uji signifikansi. Rumus pengujian hipotesis yang digunakan adalah dua arah, karena ingin mengetahui ada tidaknya hubungan antara dua variabel. 
$H_{o}=$ Tidak ada hubungan korelasi signifikan antara dua variabel

$H_{1}=$ Ada hubungan korelasi signifikan antara dua variabel

Tingkat kepercayaan signifikansi sebesar $95 \%, \boldsymbol{\alpha}=0,05$.

Berdasarkan hasil uji signifikansi korelasi Pearson yang diperoleh dari penghitungan menggunakan program SPSS, maka didapatkan nilai probabilitas hubungan antara sektor unggulan 1 (pertanian) dengan jumlah tenaga kerja sebesar 0,037. Hal ini menunjukkan bahwa dapat menolak $H_{O}$ karena memiliki nilai probabilitas yang lebih kecil dari yang ditetapkan yaitu 0,05. Dengan demikian secara statistik dapat diambil kesimpulan bahwa terdapat hubungan korelasi signifikan antara sektor unggulan 1 (pertanian) dengan ketenagakerjaan (jumlah tenaga kerja) menggunakan tingkat kepercayaan (dua arah) sebesar 95\% atau dengan $\boldsymbol{\alpha}=0,05$.

Tabel 5.17. Hasil Korelasi Pearson Variabel Sektor Unggulan dengan Variabel Ketenagakerjaan Provinsi Jambi Tahun 2002 - 2010

Correlations

\begin{tabular}{|c|c|c|c|c|}
\hline & & $\begin{array}{c}\text { SEKTOR } \\
\text { UNGGULAN } \\
\text { PERTAMA } \\
\text { (PERTANIAN) }\end{array}$ & $\begin{array}{c}\text { SEKTOR } \\
\text { UNGGULAN } \\
\text { KEDUA } \\
\text { (PERTAMBANGAN } \\
\text { \& PENGGALIAN) }\end{array}$ & $\begin{array}{l}\text { JUMLAH } \\
\text { TENAGA } \\
\text { KERJA } \\
\text { PROVINSI } \\
\text { JAMBI }\end{array}$ \\
\hline $\begin{array}{l}\text { SEKTOR UNGGULAN } \\
\text { PERTAMA (PERTANIAN) }\end{array}$ & $\begin{array}{l}\text { Pearson Correlation } \\
\text { Sig. (2-tailed) } \\
\mathrm{N}\end{array}$ & 1 & $\begin{array}{r}, 457 \\
, 216 \\
9\end{array}$ & $\begin{array}{r}, 697^{*} \\
, 037 \\
9\end{array}$ \\
\hline $\begin{array}{l}\text { SEKTOR UNGGULAN } \\
\text { KEDUA } \\
\text { (PERTAMBANGAN \& } \\
\text { PENGGALIAN) }\end{array}$ & $\begin{array}{l}\text { Pearson Correlation } \\
\text { Sig. (2-tailed) } \\
\mathrm{N}\end{array}$ & $\begin{array}{r}, 457 \\
, 216 \\
9\end{array}$ & 1 & $\begin{array}{r}, 888^{\star} \\
, 001 \\
9\end{array}$ \\
\hline $\begin{array}{l}\text { JUMLAH TENAGA } \\
\text { KERJA PROVINSI JAMBI }\end{array}$ & $\begin{array}{l}\text { Pearson Correlation } \\
\text { Sig. (2-tailed) } \\
\mathrm{N}\end{array}$ & $\begin{array}{r}, 697^{*} \\
, 037 \\
9\end{array}$ & $\begin{array}{c}, 888^{* *} \\
, 001 \\
9\end{array}$ & 1 \\
\hline
\end{tabular}

*. Correlation is significant at the 0.05 level (2-tailed).

**. Correlation is significant at the 0.01 level (2-tailed)

Berdasarkan penghitungan statistik (hasil output SPSS) tentang koefisien korelasi Pearson, didapatkan bahwa korelasi antara sektor unggulan 2 (pertambangan \& penggalian) dengan jumlah tenaga kerja menghasilkan angka 0,888. Terlihat nilai koefisien korelasi Pearson bernilai positif yang menunjukkan hubungan searah dan kisaran ini menunjukkan korelasi sangat kuat. Yang berarti semakin tinggi sektor pertambangan \& penggalian (unggulan 2) maka jumlah tenaga kerja akan semakin meningkat, begitu juga sebaliknya.

Untuk mengetahui apakah angka korelasi yang diciptakan benar-benar signifikan atau tidak, maka kita dapat menggunakan uji signifikansi. Rumus pengujian hipotesis yang 
digunakan adalah dua arah, karena ingin mengetahui ada tidaknya hubungan antara dua variabel. Hipotesis yang digunakan adalah:

$H_{o}=$ Tidak ada hubungan korelasi signifikan antara dua variabel

$H_{1}=$ Ada hubungan korelasi signifikan antara dua variabel

Tingkat kepercayaan signifikansi sebesar $99 \%, \boldsymbol{\alpha}=0,01$.

Berdasarkan hasil uji signifikansi korelasi Pearson, didapatkan nilai probabilitas hubungan antara sektor unggulan 2 (pertambangan \& penggalian) dengan jumlah tenaga kerja sebesar 0,001. Hal ini menunjukkan bahwa dapat menolak $H_{O}$ karena memiliki nilai probabilitas yang lebih kecil dari yang ditetapkan yaitu 0,01. Dengan demikian secara statistik dapat diambil kesimpulan bahwa terdapat hubungan korelasi signifikan antara sektor unggulan 2 (pertambangan \& penggalian) dengan ketenagakerjaan (jumlah tenaga kerja) dengan menggunakan tingkat kepercayaan (dua arah) sebesar 99\% atau $\boldsymbol{\alpha}=0,01$.

\section{Hubungan Sektor Unggulan dengan Kemiskinan}

Untuk mengetahui hubungan antara sektor unggulan dengan kemiskinan maka digunakan analisis koefisien korelasi Pearson. Dalam analisis ini hipotesis yang digunakan adalah "ada tidaknya hubungan korelasi antara sektor unggulan dengan kemiskinan di Provinsi Jambi". Variabel yang digunakan dalam menentukan hubungan korelasi yaitu variabel sektor unggulan dan variabel kemiskinan. Untuk variabel sektor unggulan terdiri dari sektor unggulan 1 (nilai LQ sektor pertanian) dan unggulan 2 (nilai LQ sektor pertambangan \& penggalian), menggunakan nilai hasil penghitungan location quotient sedangkan untuk variabel kemiskinan menggunakan nilai persentase penduduk miskin.

Berdasarkan penghitungan statistik (hasil output SPSS) tentang koefisien korelasi Pearson, didapatkan bahwa korelasi antara sektor unggulan 1 (pertanian) dengan persentase penduduk miskin menghasilkan angka - 0,914. Terlihat nilai koefisien korelasi Pearson bernilai negatif yang menunjukkan hubungan tidak searah (berlawanan) dan kisaran ini menunjukkan korelasi sangat kuat. Yang berarti semakin tinggi produktifitas sektor pertanian (unggulan 1) maka persentase penduduk miskin semakin menurun secara signifikan, begitu juga sebaliknya.

Untuk mengetahui apakah angka korelasi yang diciptakan benar-benar signifikan, kita dapat menggunakan uji signifikansi. Rumus pengujian hipotesis yang digunakan adalah dua arah, karena ingin mengetahui ada tidaknya hubungan antara dua variabel.

$H_{o}=$ Tidak ada hubungan korelasi signifikan antara dua variabel

$H_{1}=$ Ada hubungan korelasi signifikan antara dua variabel

Tingkat kepercayaan signifikansi sebesar $99 \%, \boldsymbol{\alpha}=0,01$ 
Tabel.

Hasil Korelasi Pearson Variabel Sektor Unggulan dengan Variabel Kemiskinan Provinsi Jambi Tahun 2002 - 2010

\begin{tabular}{|l|r|r|r|}
\multicolumn{7}{c}{ Variabel Kemiskinan Provinsi Jambi Tahun $2002-20$} \\
Correlations
\end{tabular}

Berdasarkan hasil uji signifikansi korelasi Pearson, didapatkan nilai probabilitas hubungan antara sektor unggulan 1 (pertanian) dengan persentase penduduk miskin sebesar 0,001. Hal ini menunjukkan bahwa menolak $H_{o}$ karena memiliki nilai probabilitas yang lebih kecil dari yang ditetapkan yaitu 0,01. Dengan demikian secara statistik dapat diambil kesimpulan bahwa terdapat hubungan korelasi signifikan antara sektor unggulan 1 (pertanian) dengan kemiskinan (persentase penduduk miskin) menggunakan tingkat kepercayaan (dua arah) sebesar $99 \%$ atau $\boldsymbol{\alpha}=0,01$.

Sedangkan, hasil penghitungan statistik (hasil output SPSS) tentang koefisien korelasi Pearson, didapatkan bahwa korelasi antara sektor unggulan 2 (pertambangan \& penggalian) dengan persentase penduduk miskin menghasilkan angka - 0,737. Terlihat nilai koefisien korelasi Pearson bernilai negatif yang menunjukkan hubungan tidak searah (berlawanan) dan kisaran ini menunjukkan korelasi kuat. Yang berarti semakin tinggi produktifitas sektor pertambangan \& penggalian (unggulan 2) maka persentase penduduk miskin akan semakin menurun, begitu juga sebaliknya.

Untuk mengetahui apakah angka korelasi yang diciptakan benar-benar signifikan, kita dapat menggunakan uji signifikansi. Rumus pengujian hipotesis yang digunakan adalah dua arah, karena ingin mengetahui ada tidaknya hubungan antara dua variabel.

$H_{o}=$ Tidak ada hubungan korelasi signifikan antara dua variabel

$H_{1}=$ Ada hubungan korelasi signifikan antara dua variabel

Tingkat kepercayaan signifikansi sebesar $95 \%, \boldsymbol{\alpha}=0,05$.

Berdasarkan hasil uji signifikansi korelasi Pearson, didapatkan nilai probabilitas hubungan antara sektor unggulan 2 (pertambangan \& penggalian) dengan persentase penduduk miskin 
sebesar 0,024. Hal ini menunjukkan bahwa dapat menolak $H_{o}$ karena memiliki nilai probabilitas yang lebih kecil dari yang ditetapkan yaitu 0,05. Dengan demikian secara statistik dapat diambil kesimpulan bahwa terdapat hubungan korelasi signifikan antara sektor unggulan 2 (pertambangan \& penggalian) dengan kemiskinan (persentase penduduk miskin) menggunakan tingkat kepercayaan (dua arah) sebesar 95\% atau $\boldsymbol{\alpha}=0,05$.

\section{KESIMPULAN DAN SARAN}

\section{Kesimpulan}

Berdasarkan hasil peneltian dan pembahasan yang telah diuraikan pada bagian sebelumnya, dapat ditarik kesimpulan sebagai berikut:

1. Sektor unggulan Provinsi Jambi berdasarkan data PDRB dan tenaga kerja selama tahun 2002-2010 adalah sektor pertanian dan sektor pertambangan \& penggalian, dimana kedua sektor tersebut selalu konsisten memenuhi kriteria analisis Location Quotient, Shift Share dan Indeks Spesialisasi.

2. Sektor unggulan mempunyai hubungan signifikan dan positif (searah) dengan ketenagakerjaan. Setiap terjadi kenaikan nilai produksi pada sektor unggulan akan diikuti dengan kenaikan penyerapan tenaga kerja. Pada sektor pertanian hubungan yang ditunjukkan searah dan kuat dengan penyerapan tenaga kerja, demikian juga hubungan antara sektor pertambangan \& penggalian dengan jumlah tenaga kerja adalah searah dan sangat kuat.

3. Hubungan antara sektor unggulan dengan kemiskinan adalah signifikan dan negatif (berlawanan arah), tercermin dari setiap kenaikan nilai produksi sektor unggulan akan diikuti dengan adanya penurunan persentase penduduk miskin. Hal ini dapat ditunjukkan adanya hubungan berlawanan arah dan sangat kuat pada sektor pertanian, demikian juga setiap terjadi kenaikan nilai produksi pertambangan \& penggalian akan diikuti dengan penurunan persentase penduduk miskin (ditunjukkan hubungan yang berlawanan arah dan kuat).

\section{Saran}

Berdasarkan hasil pembahasan di atas, penulis menyarankan beberapa hal, antara lain:

1. Pemerintah harus mengalokasikan dan memprioritaskan anggaran untuk kemajuan pengembangan sektor unggulan di Provinsi Jambi Pengembangan sektor unggulan ini mempunyai peranan penggerak utama dalam pertumbuhan ekonomi yang dapat menciptakan peluang bagi berkembangnya sektor terkait lainnya. 
2. Strategi kebijakan terkait pengembangan sektor unggulan yang dapat meningkatkan tenaga kerja, pada sektor pertanian dibarengi dengan pengembangan industri pengolahan hasil pertanian dan turunannya, utamanya sub sektor perkebunan (kelapa sawit \& karet); pada sektor pertambangan \& penggalian tidak hanya sebatas eksplorasi melainkan kebijakan pengembangan industri pengolahan hasil tambang lebih lanjut yang bersifat padat karya, penggunaan alat-alat atau mesin tambang manual, termasuk dengan melibatkan masyarakat lokal sekitar area pertambangan dalam menyerap tenaga kerja.

3. Terdapat hubungan yang negatif antara sektor unggulan terhadap persentase penduduk miskin. Peningkatan produksi dan nilai tambah sektor unggulan yang banyak menyerap tenaga kerja akan menurunkan persentase penduduk miskin melalui distribusi pendapatan. Upaya peningkatan produksi ini juga perlu didukung oleh lembaga keuangan ataupun wadah seperti koperasi sebagai lembaga penunjang untuk meningkatkan kesejahteraan pendapatan masyarakat.

\section{DAFTAR PUSTAKA}

Adam, Latif.1994. Aplikasi Model Shift-Share Analysis di Provinsi Sulawesi Utara. Jurnal Ekonomi dan Pembangunan. Vol.II. No.1. The Indonesian Institute of Sciences (PEP-LIPI), Jakarta

Amir, A. 2007. Pembangunan dan Kualitas Pertumbuhan Ekonomi dalam Era Globalisasi (Teori, Masalah dan Kebijakan), Edisi Pertama, Jambi

Amir, Junaidi, Yulmardi. 2009. Metodologi Penelitian Ekonomi dan Penerapannya, IPB PRESS, Jambi

Anonim .2009. Badan Pusat Statistik. Data dan Informasi Kemiskinan tahun 2002-2009, BPS. Jakarta .2002-2009. Badan Pusat Statistik.. Statistik Indonesia Tahun 2002-2009, Jakarta .2005.Badan Pusat Statistik Prop Jambi . Tinjauan Ekonomi Kabupaten/Kota Se Propinsi Jambi 2000 - 2004, Jambi

.2002-2010. Badan Pusat Statistik Propinsi Jambi. Jambi Dalam Angka, Jambi

.2008. Universitas Jambi [UNJA].. Buku Panduan dan Pedoman Penulisan Tesis Program Magister Ekonomika Pembangunan, Jambi 
.2001. World Bank.The Quality of Growth, PT Gramedia Pustaka Utama, Jakarta .2003. World Development Report.The Economy of Democracy, Jakarta

Arsyad,L.1999. Pengantar Perencanaan Dan Pembangunan Ekonomi Daerah, Edisi Pertama, BPFE - UGM, Yogyakarta.

.2004. Ekonomi Pembangunan, Edisi 3 Bagian Penerbitan STIE YKPN. Yogyakarta.

Asaddin dan Mansoer .2001. Pertumbuhan Ekonomi dan Kesempatan Kerja: Terapan Model Kebijakan Prioritas Sektoral Untuk Kalimantan Timur. Jurnal Riset Akuntansi, manajemen, Ekonomi Vol 1. No.1, Februari 2001 hal. 89-103.

Bendavid-Val., Avrom .1991. Regional and Local Economic Analysis for Practitioners, Fourth edition, New York.

Blakely, Edward J. 1938. Planning Local Economic Development, Theory and Practice, Second Edition. New Delhi.

Boediono.1981. Teori Pertumbuhan Ekonomi. BPFE T Yogyakarta Mada, Edisi Pertama Yogyakarta, tidak dipublikasikan.

Chen dan Ravallion. 2001. The Developing world is poorer than we thought, but no less successful in the fight against poverty. Policy Research Working Paper, The World Bank

Debraj. 1998. Development economics. Princeton University Press, New Jersey

Dornbusch, Rudiger dan Stanley Fischer .1990. Ekonomi Makro, edisi keempat, Penerbit Erlangga Jakarta, Jakarta

Dumairy. Cetakan Keempat 1999. Perekonomian Indonesia. Penerbit Erlangga. Jakarta

Elmi, Bachrul.2004. Studi Pembiayaan Pembangunan Perkotaan (urban development finance) Kota Prabumulih, Kajian Ekonomi dan Keuangan., Vol.8, No.1. Maret.

Fashbir Noor Sidin. 2001. Strategi Kebijakan Pembangunan Dalam Otonomi Daerah, Jurnal Ekonomi dan Manajemen.

Fashbir Noor Sidin. 2001. Strategi Kebijakan Pembangunan Dalam Otonomi Daerah, Jurnal Ekonomi dan Manajemen.

Hoover, Edgar .Mand Frank Giarrantani. 1981. An Introduction to Regional Economics. Third Edition. New York: Alfred A.Knopf, Inc.

Glasson, John .1990. Pengenalan Perancangan Wilayah Konsep dan Amalan (alih bahasa Ahris Yakup). Dewan bahasa dan Pustaka Kementrian Pendidikan Malaysia Kuala lumpur 
Jhingan, M.L. 2008. Ekonomi Pembangunan dan Perencanaan/ M.L. Jhingan : Penerjemah D. Guritno-Ed.1, PT Raja Grafindo Persada, Jakarta

Kuncoro M. 2000. Ekonomi Pembangunan: Teori, Masalah dan Kebijakan, UPP AMP YKPN, Yogyakarta.

Mangun, Nudiatulhuda.2007. Analisis Potensi Ekonomi Kabupaten dan Kota di Provinsi Sulawesi Tengah, Tesis. Program Pasca Sarjana UNDIP. Semarang

Mubyarto, 1989. Pengantar Ekonomi Pertanian, Teori, Masalah dan Kebijaksanaan, UPP AMP YKPN, Yogyakarta

Prihanto. PH, Syaifuddin.1996. Pertumbuhan Ekonomi dan Kesempatan Kerja di Propinsi Jambi. Jurnal Manajemen dan Pembangunan. Edisi V. FE. UNJA. Jambi

Richardson, Harry.,W. 1977. Dasar-Dasar Ilmu Ekonomi Regional. (terjemahan: Paul Sitohang). LPFE-UI. Jakarta

Rohadi, Rohendi T. 1993. Ekspresi Seni Orang Miskin: Adaptasi simbolik terhadap kemisikinan,UI Press, Jakarta

Sabana, Choliq.2007. Analisis Pengembangan Kota Pekalongan sebagai salah sotensi Ekonomi Satu Kawasan andalan di Jawa Tengah, Tesis. Program Pasca Sarjana UNDIP. Semarang

Sadau A. 2002. Identikasi Sektor Ekonomi dan Prospek Pembangunan Daerah dalam rangka Pelaksanaan Otonomi Daerah Kabupaten kapuas Hulu 1995-1999, Tesis, Program Pasca Sarjana Universitas Gajah Mada, Yogyakarta

Sarwono.2007. Analisis Jalur Untuk Riset Bisnis dengan SPSS. Andi offcet. Yogyakarta

Soekarni.2002. Ekonomi Pembangunan,YKPN, Yogyakarta

Siegel S. 1997. Statistik Nonparametrik Untuk Ilmu-ilmu Sosial, PT. Gramedia, Jakarta

Soepono, Prasetyo. 1993. Analisis Shift Share Pertumbuhan dan Penerapan. Jurnal Ekonomi dan Bisnis Indonesia No. 1 tahun III, Jakarta.

2001. Teori Pertumbuhan Berbasis Ekonomi (eksport) Posisi dan Sumbangannya bagi Perbendaharaan Alat-alat Analisis Regional. Jurnal Ekonomi dan Bisnis Indonesia. Vol.16 No.1.

Subagiyo, Edy.2009. Transformasi Struktur Ekonomi dan Disparitas Regional di Provinsi Jambi ,Tesis. Program Pasca Sarjana MEP UNJA. Jambi

Sukirno, Sadono. 1985. Ekonomi Pembangunan, Proses, Masalah dan Dasar Kebijakan, LPFE UI. Jakarta

Sulistriyanto.2004. Aplikasi Analisis Shift Share Esteban-Marquillas pada sektor Pertanian di Kabupaten Boyolali. Universitas Negeri Sebelas Maret, Surakarta. 
Sumodiningrat, Gunawan.2002. Pengantar Ekonometrika. BPFE Universitas Gajah Mada, Yogyakarta

Soeparmoko .2002. Ekonomi Publik Untuk Keuangan dan Pembangunan Daerah. Edisi pertama. Andi. Yogyakarta

Suryana, H. 2000. Ekonomi Sumber Daya Manusia. Penerbit Salemba Empat. Jakarta . 2008. Ekonomi Regional Teori dan Aplikasi, Badouse Media, Padang

Tambunan, TH. 2001. Perekonomian Indonesia, Teori dan Temuan Empiris. Penerbit Ghalia Indonesia. Jakarta

Syafrizal. 1997.Pertumbuhan Ekonomi dan Ketimpangan Regional Wilayah Indonesia Bagian Barat,. LP3S, Jakarta

Zadjius, M .2008. Analisis Sektor Unggulan dan Pergeseran Struktur Ekonomi Kabupaten Bungo periode 2001-2006, Tesis. Program Pasca Sarjana MEP UNJA. Jambi

Yuvanda, Sesraria.2009. Analisis Perkembangan Komoditas Perkebunan Unggulan dan Dampaknya terhadap perkembangan Ekonomi dan Peningkatan Daya Serap Tenaga Kerja di ProvinsiJambi, Tesis. Program Pasca Sarjana MEP UNJA. Jambi

Todaro M. 2000. Pembangunan Ekonomi di Dunia Ketiga. Ed. Ke-7. Jakarta: Erlangga

Tarigan, Robinson. 2005. Ekonomi Regional Teori dan Aplikasi, Edisi Revisi. Jakarta. Bumi Aksara

Tan, Syamsurizal.2009. Perencanaan Ekonomi (Theori dan Implementasinya). Departemen Pendidikan Nasional Universitas Jambi Fakultas ekonomi, Jambi 